\title{
Making Different Differences: Representation and Rights in Sexuality Activism
}

\begin{abstract}
This paper argues that current iterations of LGBTI (lesbian, gay, bisexual, transgender, intersex) rights are limited by an overreliance on particular representations of sexuality, in which homosexuality is defined negatively through a binary of homosexual/heterosexual. The limits of these representations are explored in order to unpick the possibility of engaging in a form of sexuality politics that is grounded in difference rather than in sameness or opposition. The paper seeks to respond to Braidotti's call for an "affirmative politics" that is open to forms of creative, future-oriented action and that might serve to answer some of the more common criticisms of current LGBTI rights activism.
\end{abstract}

Key words: Activism, Future indexed politics, LGBTI rights, Representation, Sexuality, Time.

\section{Introduction}

Recent years have seen the lesbian, gay, bisexual transgender and intersex (LGBTI) ${ }^{1}$ rights movement enjoy unprecedented visibility and relative success. While still controversial, issues of sex, gender and sexuality have enjoyed greatly increased recognition within international and regional courts and organisations as well as within some domestic jurisdictions. ${ }^{2}$ However to view these considerable gains as a simple teleological narrative of emancipation for sexual minorities is to miss the complexity of the relationship between sexuality, gender and rights in

\footnotetext{
${ }^{1}$ There are numerous versions of this acronym as well as terminology such as 'queer' or 'SOGI' and nomenclature grounded in particular locations (two-spirited, hijra, takatapui). These terms are not entirely synonymous and some of the issues of LGBTI representation are discussed below.

2 E.g. U.N. Doc CCPR/C/50/D/488/1992 (1994); UN Doc A/HRC/RES/17/19 (2011); OAS Doc AG/RES. 2653 (XLI-O/11); IACtHR 24 $4^{\text {th }}$ Feb 2012 Atala Riffo and Daughters $v$ Chile; ACHPR Resolution 257 (55 $5^{\text {th }}$ Session 2014); For a summary of ECHR caselaw see http://www.echr.coe.int/Documents/FS_Sexual_orientation_ENG.pdf (accessed 31/07/2014)
} 
global and local settings. LGBTI rights progress is complex and open ended: victory in one arena can lead to backlash or impasse elsewhere, successes may have unexpected consequences or may fail to protect the most vulnerable. ${ }^{3}$

The suggestion here is that rights and sexuality are situated within complex genealogies and specific spatial and temporal locations. To abstract sexuality and rights from the particularities of lived experience is to obscure the complex and changing role that rights can play in Sexual Orientation and Gender Identity (SOGI) politics. Moreover, a view of LGBTI rights that fails to engage with the particularities of place and space risks perpetuating an approach that is too formal and abstract to properly comprehend the current political and rhetorical complexities inherent in LGBTI rights discourses.

Of particular concern is the potential for 'mainstream' LGBTI rights discourses or forms of action to become insufficiently attentive to the complex flows of affect, identity and power operating within national and international LGBTI rights arenas. Queer and anti-racist scholarship has highlighted the dangers of viewing homosexuality in a simple binary relationship with heterosexuality without also acknowledging the racialized and class-based power relations that striate any form of queer politics (Ferguson 2005; Held and Leach 2008). Similarly, activists and scholars from diverse fields have drawn attention to the way in which a lack of sensitivity to these power relations can damage the capacity of non-Western LGBTI groups to advocate for their own forms of sexual belonging (Robertson 2012; Spade 2013; Lennox and Waites 2013; Rao 2010). I would suggest that what is required is the deployment of new categories of thought, action and affect in order to try to avoid some of the more common impasses found within sexual rights movements. In the context of this paper, I draw

\footnotetext{
${ }^{3}$ Examples of this might include Sexual Orientation and Gender Identity (SOGI) rights gains such as UN resolutions in favour of SOGI rights that are matched by an increasing focus by some states on the protection of the heterosexual family. Other examples of more complex and indirect responses are discussed below.
} 
on Braidotti and Deleuze and Guattari, in order to think 'different differences' and to explore how thinking differences might effect change within LGBTI rights arenas. Central to this project is Braidotti's insistence that:

Affirmative politics rests on a time-continuum that indexes the present on the possibility of thinking sustainable futures. The sustainability of these futures consists in their being able to mobilise, actualise and deploy cognitive, affective and collective forces which had not so far been activated (Braidotti 2009, 45).

This approach foregrounds the consideration of time and temporality in relation to the possibility of an activist politics that can bring about lasting change. As Braidotti suggests, part of the process of deploying new cognitive forces is the recognition that the particular frames by which we address current sexual rights debates are not necessarily those which will enable us to think sustainable futures. We must instead think in the mode of the future: "We have to learn to think differently about ourselves. To think means to create new concepts." (Braidotti 2009, 45).

Yet concepts of the future occupy an ambiguous space within queer politics and a number of theorists have approached affirmative politics of the future with some caution. Ahmed (2010) draws attention to the way in which the future promise of happiness can become a restrictive mode of orientation towards the future, through which we become trapped by “images of thought" (Deleuze 2011, 165) "happiness scripts" (Ahmed 2010, 59) or symbols of the future that take up all possible space (Edelman 2004, 3). These devices constrain our capacity for action or instruct us as to how we must act in order to achieve a pre-ordained future happiness. Thus aspirational politics can become a kind of restrictive "queer liberalism" (Eng, Halberstam et al. 2005, 4) or even a teleological narrative of LGBTI development to be 
"transmitted" to those who are - temporally speaking - "further behind" (Binnie 2004; Hemmings 2007; Vidal-Ortiz 2008).

By drawing on a Deleuzian framework to complement this critique we can perhaps begin to move away from a narrow conception of the future to something more open, more dangerous, but still somewhat hopeful. As Ahmed suggests: "[t]he future is what is kept open as the possibility of things not staying as they are, or being as they stay. Revolutionaries must dream; if their imaginations dwell on the injustices of how things stay, they do not simply dwell in what stays" (Ahmed 2010, 197). By situating queer critiques within a Deleuzian framework which emphasises the multidimensionality of time, we can view the "revolutionary dream" through the interplay of linear and empty time (Deleuze 2004, 89) and perhaps foreground this more nuanced view of futurity. In the actual progression of linear time, the path of the future does risk becoming overbearing or overdetermined, but in time's future dimension - the virtual empty time of aion - there is the chance to sweep away these normative restrictions. Thus what Deleuze might offer here is a means of thinking the future by which we can acknowledge the potential dangers of a politics of hope but still explore what a future indexed politics might mean.

\section{LGBTI Rights as Negative Representations and False Problems}

While the aim here is the thinking of future indexed politics, it is important to note that the focus is not just a queer politics of the future, but whether LGBTI rights specifically have anything to offer this form of thinking and acting. The retention of a rights element raises certain questions and of particular concern is the possibility that rights are 'oriented' in a way that is actively unhelpful. This note of caution draws on Ahmed's argument that orientations "are about the direction we take that puts some things and not others in our reach" (Ahmed 
2006, 56). The problem may be that rights orient us towards particular forms of being or modes of understanding that inhibit future oriented action, or even that rights themselves are too oriented towards the past, or towards particular representations to be of use. As Mignolo observes, the 'human' of human rights is not unproblematically universal; it is the "invention of Western imperial knowledge rather than the name of an existing entity to which everyone will have access" (Mignolo 2009, 10). Thus, the image of man upon which rights claims are founded - towards which they may remain oriented - is the product of a particular era of colonial violence. Rights themselves are just as problematic: the philosophical and legal grounding of current rights regimes emerged from the same period (Mignolo 2009; Kneen 2009).

This issue is reflected in Braidotti's critique of white, rational man as "the privileged referent of subjectivity, the standard-bearer of the norm/law/logos" (Braidotti 2008, 78) and the foundation of all reason, thought, representation and action (Colebrook 2006, 141). Not only does this image of man work to erase multiple possibilities for being (or becoming), it also exists as a "gigantic memory" that organises all others in binary opposition (Deleuze and Guattari 2004, 292). In this context, those who might fall broadly under the umbrella of LGBTI risk definition solely in relation to a central image of white heterosexual maleness. This framing is profoundly unsatisfying: we become trapped in unhelpful binaries of gay/straight, west/non-west, male/female, regulated by a single, central image, which is, not co-incidentally, the same image of white, rational man that Mignolo identifies as the progenitor and beneficiary of our current framework of rights and 'humanity' to which those rights attach.

The point is not that these binarisms are true. Instead, I would suggest that they are images of thought (Deleuze 2011, 165), or frameworks for thinking and knowing that orient us towards what we experience. The danger however, is that these orientations occlude the complexity of queer belonging and the way in way in which "categories presented in culture 
as symmetrical binary oppositions - heterosexual/homosexual in this case - actually subsist in a more unsettled and dynamic tacit relation" (Sedgwick 1991, 10). Moreover, an exploration of these binaries reveals the operation of the hegemonic power relations that sustain them. Thus sexuality, as Ferguson (2005) notes, is not an abstract entity but a "deployment" that cannot be read outside of the classed, gendered and racialized lenses through which it is constituted. This is echoed by Vidal-Ortez (2008) who calls for an exploration of how such hegemonies are sustained, and others who demand that we interrogate the discursive and material arrangements by which we define 'us' and 'them', heterosexual and homosexual (Rao 2010; Morgan 2000). The paucity of such binaries for reflecting queer life and the power of hegemonic practices that work to sustain them is reflected in Puar's $(2005 ; 2007)$ analysis of the co-option of elements of white, gay and usually male homosexual experience into homonationalist structures. The danger to which all these critiques allude is the possibility that queerness, queer resistance and queer futures become a single story in which certain bodies, certain modes of desiring and living are hidden or devalued (Manalansan 2005) - the queer subaltern is subsumed under binary logics and struggles to speak.

Thus we find an operation of hierarchies within hierarchies - a dominant representational legal system, grounded upon a privileged image, that sustains and perpetuates further representational binary classifications. This frame foregrounds a single and simplified dominant hierarchy and obscures that which is different or unknown to the organising logic of the hegemonic system (Santos 2007). The effect is stasis and a focus on past patterns that stymie our potential to reach creative future solutions (Olkowski 1999, 91). In the context of Braidotti's politics of the future - we become so tied to representations and binaries that we become trapped in a politics that is oriented towards the past rather than indexed upon the future. 
This suggests that a more critical approach to the oppositional categories that seem to striate any form of LGBTI politics is necessary. At issue is the structural question of how we express resistance or activism while moving away from of the idea that resistance must always be posited in terms of oppositional categorisations and negation (Braidotti 2009, 44). Of particular use here is a Deleuzian dialectics which critiques the oppositional positioning of identity categories. For Deleuze, contradiction hinders our capacity to grasp the multiplicitous operation of positive differences. The negative reduces experience or identity to a false problem that hinders our grasping and understanding of it (Deleuze 2011, 268). What Deleuze invokes here is a difference that is greater than, and goes beyond contradictions that makes difference compatible with identity or representation: an affirmative or positive difference, "the difference that synthesizes diversity more concretely than the Hegelian identity of identity and difference." (Widder 2003, 459).

Our starting point then, is not the negative or the binary, but the problematic, or a virtual multiplicity. A politics or a form of rights claim that defines itself through an oppositional dialectic is a false framing or a false problem. There is no requirement for sameness or for representation; instead the dialectic is a positive expression of virtual multiplicity through the particular and the actual (Deleuze 2004, 107). The key concern must be with the play of difference and the differential and divergent chains of meanings and multiplicities that ensue. What this suggests is that the heterosexual/homosexual binary is always a false problem. A rights-based solution that simply seeks to define homosexuality as 'not-heterosexual' (or vice versa) and to gain equal rights for homosexual/LGBTI/queer/SOGI individuals based on categories that are defined in relation to heterosexuality as the central, normalising image, will never be enough. Moreover in the context of queer/LGBTI/SOGI politics, identity categories that are defined against heterosexuality obscure differences within a queer community which are themselves positive and multi-layered. 
This raises the question of whether foundations for action can be rooted in difference rather than in sameness. LGBTI rights are restricted by a demand that queers resemble (as closely as possible) heterosexuality or that non-Western and post-colonial sexualities adhere to patterns set by Western rights politics (Robertson 2012; Rao, 2010). A critique of this position does not reduce the possibility of positive cross-communication; the point is instead that LGBTI/SOGI will never be fully 'representable' in this frame. LGBTI is not the opposite of heterosexuality, but instead resonates alongside, around and in relation to heterosexuality. All such resonances, including heterosexuality itself, are differential, changing and unfixed expressions of what it is to be desiring or loving or connected within space and place. As such, both LGBTI and other sexual rights could be viewed not as simple, identifiable content or forms of action but as a question of questions, differences and the possibility of making old demands in new and different registers.

While this more positive framing of the dialectic offers significant theoretical and practical tools for unpicking LGBTI rights politics, it also makes substantial demands. Not only does it seek to dismantle dominant frameworks and identities (white, heterosexual, male) it brings all identities (queer, black, transgender, poor, nomadic etc.) into question. Thus while we might welcome the challenge to totalising schemas of memory that place the white, heterosexual man as the organising centre, Deleuze's framework goes further than this, dissolving identity and subjectivity within the play of difference. By questioning the power structures that dominate representational thinking we question the mechanisms by which all individuals and groups function within that system, not just its beneficiaries. Some caution might be required here: it is much easier to give up a subjecthood that one already has than a recognition which one has yet to acquire (Braidotti 2003, 12; Hickey-Moody and Ramussen 2009). Nonetheless, a productive resonance remains between feminist calls to 'think things 
differently' (Grosz 2000, 1019), Deleuzian paradoxes and activist critiques of sexuality politics, the question is one of how this resistance might be mobilised within a politics of rights.

\section{The Paradox of Rights}

The issue identified above was the problematic oppositional framing of identities reified in a rights discourse. The solution might be found in an exploration of whether there can be a politics of rights that, rather than proceeding through contradiction and negation in which identity is defined through othering, seeks connections and disavows negativity as the basis of identification or action. Can there be a re-figuration of our framing of rights to the extent that they can escape past-oriented frameworks and negativity into positive difference? Or do rights remain "moral-intimate-economic-good-life fantasies" which actually inhibit our flourishing (Berlant 2011, 2)? More succinctly, can we conceive of a rights politics in which we 'counteractualise' or replay our response to injustices differently?

My suggestion is that 'abstract' rights that are disembedded from historical and temporal locations will struggle to move beyond problematic and static representations. Yet there remains a productive potential that is directly linked to the capacity of rights to paradoxically inhabit two different, contradictory positions at the same time. Thus, while rights can become a restrictive shorthand through which we articulate desire or injustice within a limited framework, there remains a second, immanent operation of rights that exists as an unactualised element, or a surplus that rights may attempt to re-capture but fail to adequately express (Douzinas 2000, 226). This virtual escape could be found, for example, in the current rights victories, particularly in Western states, that afford legal protections for marriage to gay couples, while failing to adequately address issues of poverty, marginalisation or discrimination among less privileged communities that still fall broadly under the Lesbian, 
Gay, Bisexual, Transgender, Queer, Questioning, Intersex (LGBTQQI) ${ }^{4}$ umbrella (Spade 2013). It is found in the way in which particular non-Western LGBTI rights groups have adopted the language of LGBTI rights, whether it is suitable to their needs or not, in order to access global and regional support and funding (Sekinelgin 2009, 104). Furthermore, it is found in the exuberance, energy and creativity of groups calling for sexual minority rights that is rarely fully captured within rights language. The image of drag queens rioting in the New York streets or of the bravery and creativity of marginalised groups demonstrating and working in areas where homosexuality or gender variant behaviour can bring severe opprobrium from state or local communities operates in a register distinct from (although intersected by) doctrinal rights frameworks.

This therefore is the paradox of rights: they can resonate in both liberatory and restrictive capacities - often at the same time. Rather than resolving this paradox, of interest here is a focus on rights as active processes. We can frame a right not through negation and opposition or as attached to a particular identity, but as a drawing together of a particular set of series or affects within a particular location. This means that at issue is the question of how rights interact with moments of dynamism and change, and thus we must consider not only what is deemed relevant or irrelevant within particular conceptions of rights, but also what happens when our preconceived understandings of rights fail us. The key moment is that when our rights language or images of thought, law or identity are unable to adequately capture (or actualise) the demands of a particular case. I would suggest that this is the moment of openness to a future indexed politics - it is the point when rights 'stutter' or fail to immediately provide a framework through which we might think or represent a solution. The stutter brings into question our established assumptions and frames for action and challenges us to comprehend

\footnotetext{
${ }^{4}$ This is a broadening out of LGBTI acronym, and is used here to give an indication or the range of identities and behaviours under consideration. Given this diverse range, it is perhaps unsurprising that 'LGBTI rights' narrowly conceived, will fail to capture the full range of issues faced by sexual and gender identity minorities.
} 
the reformulation of the new. In this moment, the different, the future and the queer is expressed not through negation or opposition but as the moment of thinking different futures.

\section{Rights in the Time of the Encounter and the Event}

What is needed here therefore, is a movement from the 'stuttering' of rights towards the grasping of 'different' solutions - from thinking different differences to making different

differences. In this context, the stuttering or failure of rights might be framed as a Deleuzian encounter: a moment which forces us to think rather than to act according to pre-ordained habits (Deleuze 2011, 176). This is a moment in which we might potentially see the actualisation of the virtual in response to the demands of the actual, or the moment when the image of thought is disrupted or destabilised. This is also the space that Berlant refers to as the "impasse of the present", a potentialised "space of lag" (Berlant 2011, 4, 263, 35). The impasse or the encounter can be a stuttering space of suspension in which normal rules of progress or of responding to crisis are suspended, thus mediating new modes of repeating the future. The encounter or moment of disruption here acts as the actual side of a two-sided event in which an event is the virtual transformative effect, existing on a plane of immanence (Stagoll 2010, 90). In this context therefore, encounter and event hint at transformation.

We should note that an event as conceptualised within a Deleuzian framework is not something that we can force or anticipate. Events are not material or actual, but instead consist of virtual movement (Reynolds 2007, 150). Thus there is no simple causal relation between encounter and new conditions, but a relation between the two series of actual and virtual mediated by the event. The actual (encounter) determines new relations among virtual conditions, which are then actualised through the event and as such, events signify a reordering, or a release of connections in which previous forms or series are reconstituted and 
new forms of action are released or actualised (Williams 2008, 141). This means that an event is not a new beginning but a "novel selection in an ongoing and continually altering series" (Williams 2008, 2). Most crucially the subject is not the centre or the cause of the event - we do not bring about events in the sense that we could plan for or control an event's virtual movement or its transformative effects. Instead the event makes a demand which we must attempt to answer - we must "become worthy" of the event by replaying it as a "counteractualisation", that is, by drawing out the eternal virtual event and replaying it with reference to the particularities and contingencies of our material circumstances. For Williams:

We cannot be worthy of the event unless we strive to express it through others and for others and in response to others' expressions, unless we strive to connect it to others, as far as its potential and our potential to carry it. We cannot be worthy of the event if we pretend that this communication is one of identities or between identities. We cannot be worthy of it, if we claim to be blocked by final negations, or governed by untouchable and invariant transcendences, values or laws. To be worthy of the event is to redouble it by creating a synthetic communication through disjunction, variation and difference, refusing pure opposition (Williams 2008, 168).

Action in the event must be both particular and singular and a counteractualisation of a universal or eternal movement that will be played or counteractualised differently by others (Williams 2008, 149). This form of counteractualisation demands a sensitivity to the interplay of linear and empty time and foregrounds the complex and multidimensional understanding of time found within Deleuzian thought (Williams 2011, 9, 145-7). For Deleuze, time is a multiplicity and the present is not one process, but multiple processes in which present, past 
and future occupy different determined or determining roles: "Every process is multiple, irreducible to others and free of claims to higher sources or pure origins.... There is only the demand to be worthy of the complex process making all things become together, but never as one" (Williams 2011, 4).

Similarly, within this perspective, time is not a form of receptivity in which incidences occur, but is itself the pre-individual ground for different dimensions of temporality (Williams 2011, 5). Habit and memory are different modalities or different dimensions of time and both are disrupted by the demands of the event in which the cycle of time is fractured and time is thrown "out of joint" (Deleuze 2011, 111). This is Deleuze's 'third synthesis' of time, the synthesis of the future in which empty time, free of cyclical repetitions and actual objects, is distributed on either side of a crack or "caesura" (Deleuze 2011, 111). In this repetition, time is divided into two series in relation to the caesura: "there are forms that cannot return and that are consigned to remain past forever and there are forms that return with the cut that are relived with it" (Williams 2003, 103).

It is through asking what calls up this third synthesis and empty time that Deleuze frames the demand of event as the drawing of action from memory and its contemplation in a way that facilitates the becoming-capable and becoming-equal to action (Olkowski 1999, 140). In this becoming capable of the third synthesis, the future is 'discovered', the I is cracked and time surges forth between the ego and I. This is the repetition of the future, which as actors, we cannot anticipate or control, but only become equal to the movement of the virtual that breaks and reorders our temporal and subjective orders.

This is why Deleuze finds Nietzsche's concept of eternal return so important. What returns are not identities, but singularities or elements which return and repeat in all different possible combinations. Repetition exceeds the virtual past it repeats and the present in which it emerges, producing the future as a new combination. The pure event, as the hub around 
which divergences resonate is what draws the before and after together, but is also that which does not occur at any moment while haunting all moments. Here, Deleuze and Guattari's notion of 'becoming' is vital (Deleuze and Guattari 2004, 261). In this context, becoming involves the extraction, contemplation and repetition of singularities in new modalities and combinations, new lines of flight. The third synthesis of time expels the restrictive, identitarian forms of the past and the present in favour of the new, the imperceptible and the becoming. As such, referring to "becoming-woman", Burchill argues:

Put as succinctly as possible, becoming-woman as a mode of repetition constitutive of the future is distinguished from the repetition or reproduction of feminine gender traits, in that, instead of contenting itself with including difference as a variant with (an enlarged field of) the Same, it extracts from the sedimentation of the past, elements 'pertaining to difference', which it then enfolds - or reiterates - in new configurations that no longer take their bearing from the past as it is congealed, nor from the present as the deployment of variations informed by the past (Burchill 2010, 94).

This is the repetition of the future, the reiteration of the new. The event becomes a demand for action - not in a pre-ordained pattern, but as a counteractualisation that replays the virtual according to the exigencies of the particular and in doing so, neither falls back into the habits of the past nor mimics the present, but repeats and reinvents the future. In relation to sexuality, this process would not simply bring LGBTI rights to the fore, but would resonate in such a way as to re-figure the way in which we understand and embody social justice and belonging. The event refigures the plane upon which we are able to work, it enacts a change in self and social machine. Thus it can reorient questions of what rights are, what they can be 
and what connections they can make. This therefore is how we might think Braidotti's future indexed politics. The point here is not to impose a form upon the future, nor is it a frame that embraces negativity or opposition according to the dictates of dominant powers or schemas of memory. Instead it seeks to think 'different differences' and to counteractualise the event through un-thought lines of flight.

Thus the failure of rights, their limit at which they struggle to encompass the enormity of demands made or injustices felt may constitute an encounter - a moment in which we stutter and pause. This stutter occurs in a number of dimensions; it interrupts the habitual flow of memory and recollection, but in doing so, it allows for the emergence or engagement of minor practices within the major in which we may think the "untimely" (Deleuze and Guattari 2009, 111). Stuttering is a double movement - not just a moment of critique but simultaneously a moment of affirmation of difference, or an act of creation or creativity. As such, we are neither entirely free agents able to comprehend and actively synthesise the past and present, event and action; nor are we simply passive pawns subject to temporal synthesis. The event makes a demand for counteractualisation that is projected into an image of action in the future. The encounter challenges our comprehension of our preordained forms. Through event and encounter we can begin to comprehend the complex interplay of virtual and actual in which difference, rather than identity or negativity, demands future oriented action.

\section{Rights and the Untimely}

This exploration of Deleuzian temporalities develops the rationale behind a future indexed politics, but still struggles to translate into a sustainable political programme. While we may avoid the dangers pinpointed in some queer critiques of futurity, the question of what it means to repeat the future as a mode of action and more specifically as a mode of LGBTI political 
action remains. The failure of rights makes a demand that we think differently, through new concepts, and in doing so creatively repeat the future in new and unanticipated ways. As such, Flieger has argued that what occurs is the making of history by those who are out of line, those who "play the game wittily" (Flieger 2000, 62) or those who create a new game by dissolving the rules and bringing new conjunctions to bear. Inherent to this is a becoming-equal to the event, a playing out of the break of linear time and a repetition of the future. This is a mode of political action that works by following intensities and articulating moments of rupture in a process of remaking, not to create a history that is 'true' but to attempt to work within a frame that acknowledges the multiplicity of history, the virtuality of memory and the myriad contractions and rotations through which we can leap into the past.

The goal then is an affirmative ethics that repeats the future instead of mimicking the past. It seeks the actualisation of virtual events or the "memory of another past" (Al-Saji 2004) in which the actualisation of the non-actualised lines, the excluded and forgotten planes, are rethought. Such micropolitics and linkages between forces will be constantly unstable, habitually unseen and ever changing. We could argue that many political movements might begin by displaying this radical potential for becoming and for the creation of new lines of flight. But the thinking of the untimely is not an easy task and it is often too difficult to sustain - the image of action or the event in need of actualisation is too big and politics falls back into representation and identity.

However, even when representational identity politics are at their height, it is possible to identify potential micro-movements, partly hidden and reverberating below and around larger representations. There are a number of examples of LGBTI movements operating effectively by positively articulating varied positions from within the midst of a fragmented coexistence. Hutta for example, suggests that Somos-a gay activist organisation based in São Paolo - was able to give the "best proof" of its existence and demands during its greatest crisis 
of factionalism (Hutta 2010, 148). Similarly, one of the most significant modern symbols of gay liberation began not with coherent political action but with drag queens rioting in New York Streets (Wald 2000, 3). Such moments - or events - can function as outpourings of intensity through which the connections that striate our society are re-worked or called into question. In the UK, the emergence of the Gay Liberation Front (GLF) in relation to the older Campaign for Homosexual Equality (CHE) operates as a moment of radical rupture, when LGBTI individuals began to speak for themselves in public debates, "not to be fearful to ask for what they wanted" (Jivani 1997, 172). In each of these cases we can identify an encounter which calls 'old' modes of action or identity into question and makes a demand that we repeat in the mode of the future.

In this vein, Grosz calls for a politics of imperceptibility that instead of seeking 'visibility' or 'recognition', works through:

[A]ctions, effects, consequences, forces which generate transformation without directing that transformation to other subjects who acknowledge its force...Political struggles on such a model are not directed to affirming categories or classes of subject, but categories or classes of action (Grosz 2005, 168).

The Stonewall riots, Somos, and the GLF were all engaged in some form of imperceptible politics. This does not mean that they were not also engaged in wide ranging debates about nomenclature and about inclusion and exclusion from state bodies; but their effects can also be measured in terms of impact and movement. Such events refigured what was possible in terms of the actual, but also in terms of flows and intensities of virtual objects and actualised histories. Key to this mode of action is an emphasis not on identity, recognition 
and opposition, but on movement, force and intensity. This might be thought of as a politics of future oriented action that seeks effects and movement rather than certainty and identity. The frame of reference is shifted and different questions are asked.

However, while an imperceptible politics may shift the focus to address many of the issues of framing, representation and negativity that currently populate LGBTI rights discourses, we should be cautious in wholeheartedly accepting it as a solution to the issues raised above. While the actions and effects of Somos, the Stonewall Riots and the GLF were hugely significant, the intensity of the groups or movements themselves were relatively short lived - the GLF lasted only 4 years (Jivani 1997, 169). Other incarnations of radical lesbian and gay political groupings experienced similar intensity followed by disagreements, movement and change (Lucas 1998). The intensity or radical potential of the caesura does not exist easily in linear time, although moments of its emergence can be traced on both sides of the event. What is significant about these events therefore, is that they feature a challenge to, or even an overturning of previously articulated categorisations and normative standards at the same time as (or even by means of) an intensity that is difficult to extend into the progression of linear time.

Such breakdowns highlight the difficulties of thinking activism, time and events. Becoming worthy of the event demands that we repeat in the mode of the future and accept the possibility of undoing of old identities, connections and flows. Imperceptibility is therefore a precarious position from which to implement sustainable political action.

\section{Pride, Rights Activism and Embedded Imperceptibility}

Thus imperceptible politics is necessarily open ended and risky. Two risks in particular remain to be addressed. First is the potential that imperceptibility or 'micropolitics' be 
unquestioningly viewed as 'the solution' and the marginal and disenfranchised unthinkingly embraced as 'the future'. This approach valorises marginality but does not necessarily pay attention to the specific, embodied difficulties of those who actually occupy the margins. This critique underscores the geo-political cartographies of power relations that must be accounted for within this framework: repeating the future and the event involves the shattering of preordained frames for action, knowledge or identities. And as Braidotti reminds us, it is much easier to give up a subject position or an identity to which one already has access than to denounce subjectivity or recognition that one has yet to acquire (Braidotti 2003, 12). We may be trapped within a false framing, but at least it is a framing that is known. For activists, for the poor, the disenfranchised, women and others, the price of transformation remains high. The image of thought, habit, structure and rights, while less transformative, may offer a safer pattern for change.

The second danger to be addressed is the possibility that once radical forms of action become 'overcoded' or "blocked memories" (Williams 2003, 43). For example, the Pride movement can trace its genealogy back to Stonewall, which heralded a seismic shift in the way in which gay activism formulated itself (Enguix 2009, 18; D'Emilio 2000), yet a number of studies have documented an increasing view that Pride has become commercialised, depoliticised and exclusionary (Johnston 2005, 105; Bell and Valentine 1995, 14; Enguix 2009; Holt and Griffin 2003; Kates and Belk 2001). Thus while the former critique of imperceptibility overdetermines the micro and the marginal in politics, in this latter case, habitual repetition risks losing all traces of it.

I would suggest that both of these dangers can be addressed through a careful reading of Deleuzian dialectics and spatiality. Particularly useful here is Nunes' reading of the virtual/actual relationship as dyadic rather than binary. Nunes notes that there is no a priori form through which the virtual may be known or actualised, what matters is that the virtual is 
present in different forms through each actualisation. The exclusionary opposition of virtual/actual is not quite correct: what matters is that there be virtuality or deterritorialisation in each act, not that it take a particular form (Nunes 2010, 110). Micropolitics does not necessarily have to be small or discontinuous to be micropolitics - instead it must express virtual conditions in the actual. As such, a politics of futurity is freed from the expectation that it will take a specific route - as Nunes suggests it is not a choice between 'the flux' as radical, singular change and 'the party' as its opposite but between what different forms of action best express virtuality given the contingencies of any given situation (Nunes 2010, 114).

The point here is that to express pure virtuality would be to dissolve. Instead we must think and know the virtual through the particularities of the actual. Our actions and representations should seek to express this virtuality within the constraints of the actuality within which we are enmeshed. As Braidotti notes, minority groups themselves must also seek to 'become-minoritarian' - the form of a group, its size or its purpose does not automatically ensure that it will be repeating the future (Braidotti 2006, 79; Braidotti 2008, 84). We should not seek to impose a form on the type of action required, but should instead look to the effects, movements and orientation of those actions.

This analysis gives some insight into the critiques of Pride outlined above. What is repeated in marches and carnivals that seem to have become depoliticised is a form of action rather than the intensity of the event. Pride zig-zags between the passionate intensity of Stonewall, the carefully choreographed street parties of Soho and the courageous defiance of Ugandan LGBTI activists marching with rainbow flags despite the very real danger that such an action poses. ${ }^{5}$

\footnotetext{
5 Val Kalende "Gay Ugandans: Loud and Proud” Huffpost: Gay Voices (15 August 2012) Retrieved 11/04/2014 from http://www.huffingtonpost.com/val-kalende/gay-ugandans-loud-and-proud_b_1785222.html
} 
This temporal reading can be further developed through an analysis of Pride and space. For Deleuze and Guattari, space is "a discursive practice of place" (Conley 2005, 261) and exists on a continuum or within a polarity of smooth and striated spaces. Striated space is space which is organized: the space of "walls, enclosures and roads between enclosures" (Deleuze and Guattari, 2004, 420). Smooth space is the open space of movement, the space of multiple directions and variability (409). What is significant however is the way in which smooth and striated space do not exist in opposition but are found within each other - smooth space haunts the striated and can disrupt and subvert the striations of conventional space (Deleuze and Guattari 2004, 424; Philippopoulos-Mihalopoulos 2010, 10).

This is of particular relevance when we consider how much LGBTI activism consists of disrupting or 'queering' spaces. Pride marches can 'occupy' formerly 'straight' streets (Binnie 1995, 197). They disrupt the way in which bodies move through space, challenge our expectations of how these bodies behave in public spaces (Kates and Belk 2001, 398) and thus the means by which space is striated. Yet this need not always be the case: the disruption may be temporary or have no lasting effect (Mason and Lo 2009, 114), it may, as suggested above, lose its disruptive force to commercialisation or other disciplinary forces thus becoming more territorializing than deterritorializing (Bell and Valentine 1995; Johnston 2005). Moreover, Pride risks becoming the only means by which resistance can be expressed, in which visibility becomes the only means of liberation (Vidal Ortez 2008, 480) or more worryingly a means by which being LGBTI friendly might be seen as a marker of civilization or modernity and a mode by which other injustices are ignored (Puar 2013, 336). All these critiques highlight the way in which Pride itself is a means of deterritorializing and then re-territorializing space, there is no guarantee that in this re-territorialization, all bodies will be equally comfortable or welcome (Manalansan 1995; Puar 2002). 
What is significant therefore is the materiality and spatiality of Pride - or any form of LGBTI activism. What is at stake is not simply discourse or symbolic repetitions, but bodies moving in space, or bodies situated within, shaping and moving across an uneven terrain. As Malins suggests:

[T]he relationship between bodies and spaces is one of folding. The world around us folds into our bodies; shaping not only our movements, postures, emotions and subjectivity, but also the very matter of which we are composed. We are folded by our genes, the food we consume and the air we breathe; by sound, texture, light and taste; by our relationships with others, and our interaction with the space around us. At the same time, bodies continually fold out into the world: shaping - and transforming - the spaces and places around them (Malins 2007, 158).

We are folded into the space that we occupy and therefore our resistance must be firmly tied to this spatial context. This brings into question the concept of imperceptibility that proved useful above. In particular, Braidotti suggests that Grosz's and Deleuze's approach to imperceptible politics is insufficiently attentive to the material, embedded context of geopolitics and power relations (Braidotti 2008, 106). While imperceptibility suggests a lack of presence, perhaps what is needed is in fact an 'embedded' imperceptibility. We must remain open to the demands of the future, but with a keenly focused understanding of the specifics of space and the bodies moving and connected within that space. Space is not neutral and even the most striated spaces will be haunted by the smooth. Thus Halberstam notes: 
Gay pride may well be a massive consumer opportunity as its critics have astutely pointed out, but not everyone is "buying." For some folks, gay pride is the only "gay" thing they do all year; for others, the opportunity to march within ethnic groups that tend to be marginalized by white gay communities makes gay pride an important site for the disruption of a monolithic association of gay identity with white gay masculinity (Halberstam 2005, 223).

Thus we cannot and should not universalise the form that resistance might take - what matters is that it is present. Smooth spaces can be followed even when they arise within the midst of a striated space, and the encounter can make us stutter and pause even within the context of the everyday. What matters is how we orient ourselves towards the world and to do this we must be embedded within that world and enfolded within its spaces.

This focus on intensive movement, becoming and the spaces of the actual reframes the demands that LGBTI groups must make of themselves. In this framing, difference and future repetition replaces opposition and negativity as the catalyst for action. Thus returning to the example of Pride, it could be suggested that two very different contexts - Uganda and Stonewall - could both express virtual movement with reference to the specificities of place and time, while not resembling each other in any particulars, or even adhering to identical identity categories or political demands. What is significant is the active positive force of such actions rather than the idea that actions will take particular forms. Thus within this frame, difference is no barrier to connectivity, nor must action take the form of endless repetitions of past actions, through which each act is subsumed into the identity of that which has gone before. Stonewall is only prior to the Ugandan Pride march in the linear sense - in the context of virtual movements, both might be viewed as equal repetitions of the same theme, embedded within their particular locales. To suggest that Ugandan Pride is a simple replication of Stonewall, or 
of current Western iterations of Pride is to do a disservice to the particularity of the Ugandan context and the actions of those involved.

At stake is a question of how we respond to uncertainty or to the stuttering encounter. And while an imperceptible politics would not demand a particular form of response, there are perhaps certain characteristics that might be emphasised. First, any response must be sensitive to a "starting position of asymmetrical power differentials" (Braidotti 2006, 130) and to the material, grounded reality of the politics of location. Intimately related to this is the need for those who assume identities or occupy spatio-temporal coordinates most associated with power to decentre themselves as the locus and impetus for all action. Second, the key focus of any response will be intensity over form of action. Third, we must recognise that future oriented action holds the potential for the dissolution of identities, thus clinging to categories as the only direction or form for action may hinder rather than perpetuate positive action. Fourth, and relatedly, if identity categories are relegated to the sidelines of action, we must also seek connections across and through different categories in the form of novel connections and alliances. And finally, we must recognise the danger of such an approach. Deleuze does not offer a coherent pattern for action, nor does he envisage the line of flight as a simple path to freedom (Deleuze and Parnet 2006, 104). Instead we might envisage this framing as a challenge to which we must respond.

Significantly, this process is firmly grounded in particular, actual locations. What is needed here is not transcendent imperceptibility but action that counteractualises the virtual with reference to the contingencies of space and place. We should note that Berlant's impasse is both a spatial and temporal term, demanding a 'hypervigilance' to the materiality of the world (Berlant 2011, 4). Imperceptibility demands that we re-frame the way in which we approach and view the singularities at play in any particular circumstance, in order to think not 
in terms of a singular identity but in terms of the relations of movements, flows, forces, affects and individuals that are singular to that particular locale.

Thus thinking differences and making differences form part of a single process of active becoming. Thinking new concepts and actualising virtuality within the specificity of the actual are part of the same action. This is why Braidotti calls for thinking sustainable new futures through the mobilisation, actualisation and deployment of new cognitive, affective and collective forces. The task for critical theory, she suggests, is to ethically assess and format these forces (Braidotti 2009). The critical form of action here appears to be one in which we think futurity when we are faced with critical encounters. A commitment to this form of action demands that we are receptive to connectivity grounded in difference rather than similarity.

Where then, does this leave the question of LGBTI rights? Once again a spatial analysis proves useful: the law itself might be thought of as both a legal terrain and a mode by which legal and non-legal spaces are striated. We might argue that rights in their most common form stratify and striate the past, give present spaces order for action, yet cannot hold in a repetition of the future. Transformation requires the breaking of sedimented structures, into new actions and new becomings. The rights discourse seems to require the recognition of identities, but if the potential for change inherent in the rights discourse is pushed to its limit, the very process that secures the recognition of identities (as well as the identities themselves) becomes defunct. Yet it is in this failure of rights that we might stutter and pause and in doing so contemplate new possibilities for action. And within this tension the law's own spatialities and temporalities can both recognise their limits and perhaps seek their own growth and becoming (Lefebvre 2009, 216). The point of transformation and change is therefore not that the future resembles the present with more identities added to the tally of the 'recognised', but that the relations that constitute the present are broken. It is in this moment that we might find a rights politics that 
questions the very categories that it uses, and the potential for an imperceptible, virtual politics that may or may not draw upon the rights discourses from which it has grown.

\section{Conclusion}

Currently, the LGBTI rights discourse fails or at least, struggles to fully articulate itself through the tools at hand. However, rights remain productive, not as a means of adding yet more minoritarian identity groups to the 'side' of the 'recognised' citizens, but as a means by which the totality of the problematic system can be exposed. Both within and without the LGBTI rights movement, activists, lawyers and individuals remain deadlocked in a series of arguments that reveal the limits of the identities, histories and structures within which we fight (Girard 2007). The task then is not to read this fight only in terms of the identities, histories and structures which contain and restrain us but to change the rules of the game. ${ }^{6}$ The binaries through which we articulate our battles should not be viewed in terms of irreducible, irreversible blocks of matter which can do nothing but clash with each other, but as articulations within the flux and flow of becoming. They are products of time place and event, and can be read as a demand for a situated imperceptibility.

This however, is a terrifying process. It is also the reason why Braidotti's critique resonates so forcefully: why give up what little we have achieved in order to embrace uncertainty and unknowability? And we should note here, that while Deleuze and Guattari may privilege the line of flight, nothing in their writing is unambiguously good or bad. A limited freedom, or at least a plan for how to fight in registers and languages that are known, are surely much safer than freedom in an uncertain, unknowable register. Descending to the depths of memory and returning in unknowable forms is both awesome and frightening at the

\footnotetext{
${ }^{6}$ For a discussion of games and coding in the context of Indian decolonisation see Connell 2007, 186
} 
same time. We are left then, at a standstill or perhaps at a stuttering pause: at a point at which a decision must be made - to dive into the virtual and repeat in the mode of the future, or to remain in the mode of the present, with the structures of identity, rights and negation and all that they engender. Becoming involves the affirmation of chance and of difference at every level, not just at the level of whether we will win or lose a particular case or achieve the articulation of a particular law. The game here is for much higher stakes, the question asked is whether we are able to become equal to it, or whether we want to.

Acknowledgments Many thanks to Arturo Sánchez Garcia for his comments on an earlier draft of this article, and to the two anonymous referees who offered insightful comments and suggestions for improving the piece.

\section{References}

Al-Saji, Alia. 2004. "The Memory of Another Past: Bergson, Deleuze and a new theory of time." Continental Philosophy Review, 37 no. 2.

Ahmed, Sara. 2010 The Promise of Happiness. London: Duke University Press.

Ahmed, Sara. 2006. Queer Phenomenology: Orientations, Objects, Others. London: Duke University Press.

Bell, David and Gill Valentine. 1995. "Introduction." In Mapping Desire edited by David Bell and Gill Valentine.

London: Routledge

Berlant, Lauren. 2011. Cruel Optimism Durham: Duke University Press.

Binnie, Jon. 1995. "Trading Places: Consumption, Sexuality and the Production of Queer Space. " In Mapping Desire edited by David Bell and Gill Valentine. London: Routledge

Binnie, Jon. 2004. The Globalization of Sexuality. London: Sage. 
Braidotti, Rosi. 2003. "Becoming Woman: Or Sexual Difference Revisited." Theory, Culture \& Society, 20 no.3:43-64.

Braidotti, Rosi. 2006. Transpositions. Cambridge: Polity.

Braidotti, Rosi. 2008. Metamorphoses: Towards a Materialist Theory of Becoming. Cambridge: Polity Press.

Braidotti, Rosi. 2009. "On Putting the Active Back into Activism." New Formations no. 68.

Burchill, Louise. 2010. "Becoming-woman: A metamorphosis in the present relegating repetition of gendered time to the past." Time and society, 19 no. 1.

Colebrook, Claire. 2006. Deleuze: A Guide for the Perplexed. London: Continuum.

Conley, Tom. 2005. "Space." In The Deleuze Dictionary, edited by Adrian Parr. Edinburgh: Edinburgh University Press.

Connell, Raewyn. 2007. Southern Theory: Polity.

D'Emilio, John. 2000. "Cycles of Change, Questions of Strategy: the Gay and Lesbian Movement after Fifty Years." In The Politics of Gay Rights edited by Craig A. Rimmerman, Kenneth D. Wald and Clyde Wilcox. London: University of Chicago Press.

Deleuze, Gilles. 2004. The Logic of Sense. Translated by M. Lester and C. Stivale. Edited by Constantin V. Boundas. London: Continuum. Original edition, 1969.

Deleuze, Gilles. 2011. Difference and Repetition. Translated by P Patton. London: Continuum. Original edition, 1968.

Deleuze, Gilles, and Felix Guattari. 2004. A Thousand Plateaus. Translated by B Massumi. London: Continuum. Original edition, 1988.

Deleuze, Gilles, and Felix Guattari. 2009. What is Philosophy? Translated by Graham Burchell and Hugh Tomlinson. London: Verso.

Deleuze, Gilles, and Claire Parnet. 2006. Dialogues 2. Translated by Hugh Tomlinson and Barbara Habberjam. London Continuum. Original edition, 1977.

Douzinas, Costas. 2000. The End of Human Rights. Oxford: Hart.

Edelman, Lee. 2004. No Future: Queer Theory and the Death Drive. London: Duke University Press.

Eng, David L., Judith Halberstam, and Esteban Munoz. 2005. "What's Queer About Queer Studies Now." Social Text, 23, no. 3-4 84-85.

Enguix, Begonya. 2009. "Identities, Sexualities and Commemorations: Pride Parades, Public Space and Sexual Dissidence." Anthropological Notebooks, 15 no. 2. 
Ferguson, Roderick A. 2005, "Of Our Normative Strivings: African American Studies and the Histories of Sexuality." Social Text, 23, no. 3-4 84-85.

Flieger, Jerry Aline. 2000. "Becoming-Woman: Deleuze, Schreber and Molecular Identification." In Deleuze and Feminist Theory, edited by Claire Colebrook and Ian Buchanan. Edinburgh: Edinburgh University Press.

Girard, Francoise. 2007. "Negotiating Sexual Rights and Sexual Orientation at the UN." In SexPolitics: Reports from the Frontlines, edited by Richard Parker, Rosalind Petchesky and Robert Sember. Sexuality Policy Watch.

Grosz, Elizabeth. 2000. "Histories of a Feminist Future." Signs: Journal of Women in Culture and Society, 25 no.4.

Grosz, Elizabeth. 2005. Time Travels: Feminsim, Nature, Power: Duke University Press.

Halberstam, Judith. 2005. "Shame and White Gay Masculinity." Social Text, 23, no. 3-4 84-85.

Held, Nina, and Tara Leach. 2008. "'What Are You Doing Here?": The 'Look' and (Non) Belongings of Racialised Bodies in Sexualised Spaces." In Out of Place: Interrogating Silences in Queerness/Raciality, edited by Adi Kuntsman and Esperanza Miyake. York: Raw Nerve Books.

Hemmings, Clare. 2007. "What's in a Name?: Bisexuality, Transnational Sexuality Studies and Western Colonial Legacies." International Journal of Human Rights 11, no. $1 \& 2$.

Hickey-Moody, Anna, and Mary Lou Ramussen. 2009. "The Sexed Subject in-between Deleuze and Butler." In Deleuze and Queer Theory, edited by Chrysanthi Nigianni and Merl Storr. Edinburgh: Edinburgh University Press.

Holt, Martin, and Christine Griffin. 2003. "Being Gay, Being Straight and Being Yourself Local and Global Reflections on Identity, Authenticity and the Lesbian and Gay Scene." European Journal of Cultural Studies 6, no. 3

Hutta, J. Simon. 2010. "Paradoxical Publicness: becoming-imperceptible with the Brazilian lesbian, gay, bisexual and transgender movement." In Rethinking the Public: Innovations in research, theory and politics, edited by Nick Mahony, Janet Newman and Clive Barnett.

Jivani, Alkarim. 1997. It's Not Unusual: A History of Lesbian and Gay Britain in the 20th Century. London: Michael O'Mara

Johnston, Lynda. 2005. Queering Tourism: Paradoxical Performances at Gay Pride Parades. London: Routledge Kates, Stephen M., and Russel W. Belk. 2001. "The Meaning of Lesbian and Gay Pride Day: Resistance through Consumption and Resistance to Consumption." Journal of Contemporary Ethnography 30, no. 4. 
Kneen, Brewster. 2009. The Tyranny of Rights. Ottowa: The Ram's Horn.

Lefebvre, Alexandre. 2009. "The Time of Law: Evolution in Holmes and Bergson." In Deleuze and Law: Forensic Futures, edited by Rosi Braidotti, Claire Colebrook and Patrick Hanafin. Basingstoke: Palgrave Macmillan.

Lucas, Ian. 1998. Outrage! An Oral History London: Cassell.

Malins, Peta. 2007. "City Folds: Injecting Drug Use and Urban Space." In Deleuzian Encounters: Studies in Contemporary Social Issues, edited by Anna Hickey-Moody and Peta Malins. Basingstoke: Palgrave Macmillan.

Manalansan, Martin F. 1995. "In the Shadows of Stonewall: Examining Gay Transnational Politics and the Diasporic Dilemma." GLQ 2: 425-38.

Manalansan, Martin F. 2005. "Race, Violence, and Neoliberal Spacial Politics in the Global City." Social Text, 23, no. 3-4 84-85.

Mason, Gail, and Gary Lo. 2009. "Sexual Tourism and the Excitement of the Strange: Heterosexuality and the Sydney Mardi Gras Parade " Sexualities, 12 no.1.

Mignolo, Walter D. 2009. "Who Speaks For the Human in Human Rights." Hispanic Issues On Line Fall Issue.

Morgan, Wayne. 2000. "Queering International Human Rights Law." In Sexuality in the Legal Arena, edited by Carl Stychin and Didi Herman. London: Athlone.

Nunes, Rodrigo. 2010. "Politics in the Middle: For a Political Interpretation of the Dualisms in Deleuze and Guattari " Deleuze Studies 4 (Supplement).

Olkowski, Dorothea. 1999. Gilles Deleuze and the Ruin of Representation. Berkely: University of California Press.

Philippopoulos-Mihalopoulos, Andreas. 2010. "Spatial Justice: Law and the Geography of Withdrawal." International Journal of Law in Context 6, no. 3.

Puar, Jasbir. 2005. "Queer Times, Queer Assemblages." Social Text, 23, no. 3-4 84-85.

Puar, Jasbir. 2013. "Rethinking Homonationalism." International Journal of Middle East Studies 45.

Puar, Jasbir. 2007. Terrorist Assemblages: Homonationalism in Queer Times. Durham: Duke University Press.

Puar, Jasbir. 2002. "A Transnational Feminist Critique of Queer Tourism." Antipode 34.

Rao, Rahul. 2010. Third World Protest. Oxford: Oxford University Press.

Reynolds, Jack. 2007 "Wounds and Scars: Deleuze on the Time (and the Ethics) of the Event," Deleuze Studies, 2. 
Robertson, Colin. 2012. Decolonising Sexual Citizenship: who will effect change in the south of the Commonwealth edited by Commonwealth Advisory Bureau. London.

Santos, Boaventura de Sousa. 2007. Beyond Abyssal Thinking. Eurozine.

Seckinelgin, Hakan. 2009. "Global activism and sexualities in the time of HIV/AIDS." Contemporary Politics, 15 no. 1 .

Sedgwick, Eve Kosofsky. 1991 The Episte ogy of the Closet. Hemel Hempstead: Harvester Wheatsheaf.

Spade, Dean 2013. "Intersectional Resistance and Law Reform: Theorizing Power, Empowering Theory." Signs: Journal of Women in Culture and Society, 38 no. 4.

Stagoll, Cliff. 2010. "Event." In The Deleuze Dictionary: Revised Edition, edited by Adrian Parr. Edinburgh: Edinburgh University Press.

Vidal-Ortiz, Salvador. 2008. "The Puerto Rican Way Is More Tolerant': Constructions and Uses of 'Homophobia' among Santería Practitioners across Ethno-Racial and National Identification " Sexualities 11, no. 4.

Waites, Matthew, and Corrine Lennox. 2013. "Human rights, sexual orientation and gender identity in the Commonwealth: from history and law to developing activism and transnational dialogues." In Human Rights, Sexual Orientation and Gender Identity in the Commonwealth: Struggles for Decriminalisation and Change edited by Matthew Waites and Corrine Lennox. Institute of Commonwealth Studies/Human Rights Consortium.

Wald, Kenneth D. 2000. "The Context of Gay Politics." In The Politics of Gay Rights, edited by Craig A. Rimmerman, Kenneth D. Wald and Clyde Wilcox. London: University of Chicago Press.

Widder, Nathan. 2003. "Thought after Dialectics: Deleuze's Ontology of Sense." Southern Jounal of Philosophy, 41 no. 3 .

Williams, James. 2003. Gilles Deleuze's Difference and Repetition: A Critical Introduction and Guide. Edinburgh: Edinburgh University Press.

Williams, James. 2008. Gilles Deleuze's Logic of Sense: A Critical Introduction and Guide. Edinburgh: Edinburgh University Press.

Williams, James. 2011. Gilles Deleuze's Philosophy of Time: A Critical Introduction and Guide. Edinburgh: Edinburgh University Press. 